\title{
Changes in gene expression in the rumen and colon epithelia during the dry period through lactation of dairy cows and effects of live yeast supplementation
}

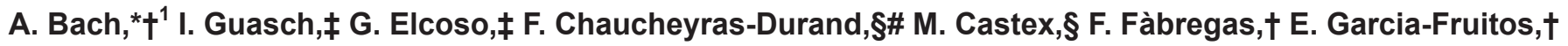 \\ and A. Aris† \\ *Institució Catalana de Recerca i Estudis Avançats (ICREA), 08010 Barcelona, Spain \\ †Department of Ruminant Production, Institut de Recerca i Tecnologia Agroalimentàries (IRTA), 08140 Caldes de Montbui, Spain \\ $\ddagger$ Blanca from the Pyrenees, 25795 Hostalets de Tost, Spain \\ §Lallemand Animal Nutrition, 31702 Blagnac, France \\ \#UMR MEDIS 454, INRA-UCA, 63000 Clermont-Ferrand, France
}

\begin{abstract}
The objectives of this study were (1) to use endoscopy to collect biopsies from the rumen and colon epithelia to describe changes in gene expression in these 2 tissues as cows move from a dry to a lactation ration and (2) to evaluate the potential influence that supplementation of live yeast could exert on these 2 epithelia. Twenty-one Holstein cows were split into 2 treatments and received either $300 \mathrm{~g} / \mathrm{d}$ of corn containing $1 \times 10^{10} \mathrm{cfu} / \mathrm{d}$ of live yeast $(\mathrm{LY} ; \mathrm{n}=10)$ or 300 $\mathrm{g} / \mathrm{d}$ of corn with no supplementation (control; $\mathrm{n}=11$ ) starting $21 \pm 2.6 \mathrm{~d}$ (average $\pm \mathrm{SD}$ ) before until $21 \mathrm{~d}$ after calving. At $14 \pm 2.6 \mathrm{~d}$ before the expected calving date, and exactly at 7 and $21 \mathrm{~d}$ after calving, rumen and colon biopsies were obtained from each cow using an endoscope. Total RNA was extracted from rumen and colon tissues, and the expression of IL10, TNFA, TLR4, IL1B, PCNA, MKI67, SGLT1, BAX, CASP3, OCLN, CLDN4, HSPA1A, HSPB1, DEFB1, and MCT1 (the latter only in rumen samples) was quantified by quantitative PCR. Overall, fluctuations in expression of the selected genes in the colon between the 2 stages of production and the 2 treatments were smaller than those found in the rumen. In the rumen epithelium, expression of TLR4 and DEFB1 was greatest before calving, with LY cows having a greater expression of TLR 4 than control cows. Similarly, expression of IL10 was greatest in LY cows before calving. Expression of TNFA in the rumen epithelium of control cows was lowest at 21 DIM but in LY cows was kept steady among production stages. The expression of PCNA and $M K I 6^{r} 7$ in the rumen epithelium was greatest at
\end{abstract}

Received May 22, 2017.

Accepted November 15, 2017

${ }^{1}$ Corresponding author: alex.bach@icrea.cat
7 DIM, indicating a high proliferation rate of this epithelium after calving. In the colon mucosa, expression of TLR 4 and DEFB1 was greater than in the rumen, and DEFB1 expression was greater in LY cows than in control cows. The use of an endoscope allowed us to study the dynamics of rumen epithelium adaptation to increased supply of concentrate after calving, consisting of increased epithelia remodeling, reduction of the $T L R 4$, and increased IL10 expression. Furthermore, the rumen epithelium of dry cows responded rapidly to live yeast, with changes in the expression of genes involved in the immune response becoming evident after $7 \mathrm{~d}$ of exposure to yeast. The expression of genes related to the immune response (mainly TLR4 and DEFB1) in the colon mucosa was greater than in the rumen, and the expression of $D E F B 1$ was further stimulated by live yeast. It is concluded that the use of an endoscope allows the study of gene expression patterns in the rumen and hindgut epithelia. We report marked changes in the rumen wall and more modest changes in the colon when transitioning from a dry to a lactation ration. Furthermore, supplementation of live yeast fostered and increased expression of genes regulating inflammation and epithelial barrier in the rumen, and in the colon it increased the expression of DFEB1 coding for an antimicrobial peptide.

Key words: colon, endoscope, epithelium, rumen

\section{INTRODUCTION}

Both the type and amount of feed consumed by lactating and dry cows differ drastically. Dry cows generally receive diets with high inclusion levels of forage and low contents of concentrate, which typically results in slow fermentation rates in the rumen (Dieho et al., 2016). Furthermore, feed intake of dry cows is commonly $<13 \mathrm{~kg} / \mathrm{d}$ (NRC, 2001), and thus digesta passage rate is also slow. On the other hand, right after calving, 
cows are fed rations with low inclusion levels of forage and high proportions of concentrate (NRC, 2001), which commonly have fast fermentation rates (Offner et al., 2003; Martens et al., 2012). In addition, feed intake increases rapidly and progressively after calving, resulting in increased digesta passage rate (NRC, 2001). Furthermore, the type and amount of forage and concentrate that cows consume influence the rumen microbial composition (Nagaraja and Titgemeyer, 2007; Fernando et al., 2010), rumen microbial activity (Bach et al., 1999), and overall rumen environment, especially $\mathrm{pH}$ and fermentation profile (Bevans et al., 2005; Brown et al., 2006; Penner et al., 2007), which all in turn can exert an influence on the epithelium of the gastrointestinal tract. In fact, several studies have reported that rumen epithelia in calves (Górka et al., 2011; Castells et al., 2013; Malmuthuge et al., 2013), dry cows (Reynolds et al., 2004), and even in cows during the transition period (Bannink et al., 2012) were affected by the type of diet offered. Most of these studies have focused on microscopic changes (Beharka et al., 1998; Steele et al., 2011b), although some have looked at changes in gene expression (Zhao and Sun, 2010; Steele et al., 2011a,b). However, little information is available about the possible interaction between the type of diet and changes in gene expression in the epithelium of the rumen (Bannink et al., 2012), and, to our knowledge, no information is available about potential changes in the large intestine of dairy cows during the transition period.

Live yeast supplementation in ruminants has been shown to induce changes in rumen $\mathrm{pH}$, microbial population, and fiber fermentation (Chaucheyras-Durand et al., 2008; Terré et al., 2015), and supplementing live yeast during the transition period could represent an effective strategy to prevent rumen dysfunction after calving (Jouany, 2006). Therefore, it is likely that live yeast supplementation, either directly acting on the epithelial cells or indirectly by altering the rumen microbial population or the ruminal environment (i.e., modulating $\mathrm{pH}$ ), may exert some effects on the integrity and activity of the rumen epithelium. To our knowledge, no study has evaluated the potential effects of live yeast on expression of selected genes in the rumen epithelium and the colon mucosa.

We hypothesized (1) that the epithelia of both rumen and colon experience changes in their barrier structure, nutrient transport, cell division and integrity, and immunological functions as a consequence of the drastic differences in both the amount and the type of rations as cows move from the dry to the lactation period and (2) that these changes may be influenced by live yeast supplementation due to its effects on both rumen $\mathrm{pH}$ and rumen microbial composition. Here we used endoscopy to collect biopsies from the rumen and colon epithelia with the objective of describing changes in the expression of genes involved in nutrient transport, epithelium barrier integrity, immune function, cell division and tissue remodeling, and cell integrity in these 2 tissues of dairy cows as they moved from a dry to a lactation ration and evaluate the potential influence of supplementation of live yeast on these 2 epithelia.

\section{MATERIALS AND METHODS}

All procedures used herein were conducted under the approval and supervision of the Ethical Committee of Institut de Recerca i Tecnologia Agroalimentàries (Caldes de Montbui, Spain). Twenty-one Holstein cows $(706 \pm 85 \mathrm{~kg}$ of BW) were split into 2 treatment groups and received either $300 \mathrm{~g} / \mathrm{d}$ of corn containing $3.3 \mathrm{~g} /$ $\mathrm{kg}$ (equivalent to $1 \times 10^{10} \mathrm{cfu} / \mathrm{d}$ ) of live yeast $(\mathbf{L Y}, \mathrm{n}$ $=10$; Saccharomyces cerevisiae CNCM I-1077; Lallemand SAS, Blagnac, France) or $300 \mathrm{~g} / \mathrm{d}$ of corn with no supplementation (control, $\mathrm{n}=11$ ) starting $21 \mathrm{~d}$ before calving (259 d pregnant) until $21 \mathrm{~d}$ of lactation. The dose of $1 \times 10^{10} \mathrm{cfu} / \mathrm{d}$ was chosen because this is the amount commonly fed under commercial conditions, the dose registered in the European Union, and the dose shown to have positive effects on animal performance in a previous meta-analysis (de Ondarza et al., 2010). At each production stage (dry or lactating), the 2 groups of cows (control or LY) consumed the same diet with the only difference being the presence or absence of live yeast. Diets were sampled fortnightly and analyzed for DM (method 934.01), ash (method 942.05), N (method 984.13), and ether extract (method 920.39) content following AOAC (1990). Neutral detergent fiber analyses were performed according to Van Soest et al. (1991). The ingredient and nutrient composition of the dry and lactation rations is depicted in Table 1 . Dry cows were housed in group pens with ad libitum access to water and feed and bedded with straw. Lactating cows were housed in freestalls, and the 2 treatment groups were kept in the same pen. Individual feed intake of lactating cows was monitored on a daily basis using electronic scales with controlled individual access for each cow to specific feed bins based on the radio frequency identification system described elsewhere (Bach et al., 2004). Treatment was applied at the cow level. Dry cows received the feed as top dressing while headlocked for 30 min during the morning feeding to ensure that the treatment delivered was entirely consumed, and lactating cows received the treatments mixed in the TMR after obtaining permission to access specific feed bins containing the designated treatment. 
At $14 \pm 2.6 \mathrm{~d}$ (average $\pm \mathrm{SD}$ ) before the expected calving date and exactly at 7 and $21 \mathrm{~d}$ after calving, about $2 \mathrm{~h}$ from the morning delivery of feed, all cows were submitted to a rumen and colon biopsy using an endoscope (CV-170 Optera, Olympus, Barcelona, Spain) equipped with a $1.68-\mathrm{m}$ probe (CF-Q165L, Olympus) and biopsy disposable fenestrated forceps (EndoJaw FB-214U; Olympus Medical Systems Corp., Tokyo, Japan). Rumen biopsies were obtained by introducing the endoscope probe, protected from chewing with a PVC tube of $2.5 \mathrm{~cm}$ internal diameter $(2.8 \mathrm{~cm}$ external diameter) and $40 \mathrm{~cm}$ long, through the mouth and into the esophagus until reaching the dorsal sac of the rumen. A biopsy (about $30 \mathrm{mg}$; capturing an entire papilla or more) of rumen epithelium from the cranial-dorsal sac was obtained, rinsed by immersion in PBS for about 3 to $5 \mathrm{~s}$, and immediately placed in RNAlater (Invitrogen, Madrid, Spain) for $12 \mathrm{~h}$ at $4^{\circ} \mathrm{C}$. Then, RNAlater was discarded and the samples were frozen at $-20^{\circ} \mathrm{C}$ until further processing. The dorsal sac of the rumen was chosen because it was easily identifiable and ensured consistent samplings, as the camera of the endoscope provided adequate vision due to the absence or low presence of rumen fluid in that area. When necessary, water and compressed air were flushed through the endoscope to remove rumen fluid from the biopsy area and locate the papillae. The entire procedure from the time a cow was restrained until the biopsy was obtained typically lasted less than 8 min. Colon biopsies were obtained using the same equipment but reaching the distal part of the colon via the rectum and using a caudal epidural anesthesia with $5 \mathrm{~mL}$ of lidocaine 2\% (Xylovet, Ceva, Libourne, France). Again, about $30 \mathrm{mg}$ of the epithelium of the distal colon was obtained at about $135 \mathrm{~cm}$ from the anus after manually emptying the rectum. Similar to the procedure used in the rumen, to identify the region of sampling, water or compressed air was sprayed through the endoscope to remove digesta and gain vision. The time required to obtain the colon biopsy (including manual emptying of the rectum) was commonly less than $7 \mathrm{~min}$. Colon samples were processed in the same manner as rumen biopsies. Each biopsy (rumen and colon) for each animal was performed with a different set of new sterile and disposable forceps.

To evaluate potential changes in the metabolic activity of the rumen and colon epithelial cells, total RNA was extracted from these tissues using Trizol (Invitrogen) to later evaluate expression of several genes. One microgram of RNA (reference no. 1708890) was reverse transcribed to cDNA using an IScript cDNA synthesis kit (Bio-Rad, Hercules, CA). The RNA purity was assessed at 260, 280, and $230 \mathrm{~nm}$, obtaining 260:280
Table 1. Ingredient and nutrient composition of the dry and lactation rations

\begin{tabular}{lcc}
\hline Item & Dry period & Lactation period \\
\hline Ingredient, \% of DM & & \\
Alfalfa hay & 5.83 & 4.96 \\
Rye grass hay & - & 9.29 \\
Fescue hay & 29.07 & 11.87 \\
Barley straw & 36.74 & 3.42 \\
Grass silage & - & 9.54 \\
Soybean meal & 14.22 & 8.04 \\
Canola meal & - & 2.17 \\
Corn grain & 4.15 & 26.99 \\
Barley grain & - & 8.91 \\
Wheat grain & 5.03 & - \\
Wheat middlings & - & 4.16 \\
Soybean hulls & - & 5.79 \\
Beet pulp & 4.31 & 3.58 \\
Calcium carbonate & 0.24 & 0.62 \\
Magnesium oxide & 0.24 & 0.17 \\
Sodium chloride & - & 0.33 \\
Mineral-vitamin premix & 0.16 & 0.17 \\
Nutrient, DM basis & & \\
CP, \% & 13.2 & 15.2 \\
NE, Mcal/kg & 1.31 & 1.62 \\
NDF, \% & 51.2 & 34.8 \\
Fat, \% & 1.67 & 2.58 \\
Ash, \% & 3.93 & 6.02 \\
NFC, \% & 30.0 & 41.4 \\
\hline
\end{tabular}

${ }^{1}$ Every kilogram of premix contained $75 \mathrm{~g}$ of sodium sulfate, $30 \mathrm{~g}$ of zinc oxide, $5 \mathrm{~g}$ of copper sulfate, $15 \mathrm{~g}$ of manganese oxide, $1 \mathrm{~g}$ of potassium iodine, $0.5 \mathrm{~g}$ of cobalt acetate, $0.25 \mathrm{~g}$ of sodium selenite, 3,750 $\mathrm{kIU}$ of vitamin A, $750 \mathrm{kIU}$ of vitamin D, and $10 \mathrm{kIU}$ of vitamin E.

ratios between 1.9 and 2.0 and 260:230 ratios between 2.0 and 2.2. Quantification of expression of genes coding for proteins involved in the immune response such as interleukin-10 (IL10), tumor necrosis factor $\alpha$ (TNFA), interleukin-1 $\beta$ (IL1B), $\beta$-defensin (DEFB1), and toll-like receptor 4 (TLR 4 ); genes involved in cell division and tissue remodeling such as proliferating cell nuclear antigen (PCNA), protein Ki-67 (MKI6 $\left.{ }^{7}\right)$, BAX $(B A X)$, and caspase 3 (CASP3); genes coding for proteins participating in the maintenance of cell integrity such as heat-shock proteins of the families A (HSPA 1A) and B (HSPB1); genes coding for proteins responsible for the integrity of the epithelium barrier such as claudin $4(C L D N 4)$ and occludin $(O C L N)$; and genes coding for proteins involved in the transport of nutrients including $\mathrm{Na}^{+}$-coupled glucose and galactose cotransporter (SGLT1) and monocarboxyl transporter 1 (MCT1) was performed by quantitative PCR using $40 \mathrm{~S}$ ribosomal protein S9 (RPS9) as a housekeeping gene, which was checked for stability following Vandesompele et al. (2002). In brief, for every control gene, pairwise variations with all other control genes were determined as the standard deviation of the logarithmically transformed expression ratios. Then, these figures were used to define the internal control gene-stability measure $(\mathrm{M})$ as the average pairwise variation of a 
particular gene with respect to all other control genes. Genes with the lowest $M$ values were considered to have the most stable expression. Assuming that the control genes were not coregulated, a stepwise exclusion of the gene with the greatest $\mathrm{M}$ values was performed to choose the housekeeping genes.

The quantitative PCR conditions for each set of primers were individually optimized (Table 2). The specificity of the amplification was evaluated by identification of single bands at the expected molecular weight in $0.8 \%$ DNA agarose gels and one single peak in the melting curve. The efficiency was calculated by amplifying 9 serial 1/10 dilutions of each gene amplicon. A standard curve of quantification cycle $(\mathrm{Cq})$ values versus log concentration was plotted to obtain the efficiency, which was calculated using the formula $10^{1 / \text { slope }}$, with an acceptable range of 1.8 to 2.1. A total reaction volume of $20 \mu \mathrm{L}$ was used containing $50 \mathrm{ng}$ of cDNA, $10 \mu \mathrm{L}$ of SYBR green fluorescent (Bio-Rad), and the optimized primer concentration for each gene. The quantitative PCR reactions were cycled as follows: an initial denaturing step of $10 \mathrm{~min}$ at $95^{\circ} \mathrm{C}$, followed by 40 cycles of $10 \mathrm{~s}$ at $95^{\circ} \mathrm{C}, 15 \mathrm{~s}$ at optimized annealing temperature for each gene, $30 \mathrm{~s}$ at $72^{\circ} \mathrm{C}$, and a final extension of 10 min at $72^{\circ} \mathrm{C}$. The resulting $\mathrm{Cq}$ values were used to calculate the relative expression of selected genes by relative quantification using a reference gene (housekeeping gene) and a calibrator corresponding to the expression of HSPB1 from a randomly chosen control cow at $2 \mathrm{wk}$ before calving following the method described by Pfaffl et al. (2004). The calibration allowed for direct expression comparisons among genes and sites.

Animal was the experimental unit. Gene expression data were checked for normality, and those not fitting a normal distribution (IL10, TNFA, IL1B, SGTL1, $H S P A 1 A$, and DEFB1) were log-transformed prior to any further analysis. Results in tables and text correspond to back-transformed means, whereas standard errors and significance values correspond to transformed data. Gene expression values were fitted to a mixed-effects model that accounted for the fixed effects of treatment, stage of production $(-14,7$, and $21 \mathrm{~d}$ relative to calving), and their 2-way interaction and for the random effect of cow. Production stage entered the model as a repeated measure using the compound symmetry structure as it yielded the lowest Bayesian information criterion values. Also, a mixed-effects model accounting for the random effect of cow and the fixed effects of site (rumen vs. colon) and production stage ( $-14,7$, and $21 \mathrm{~d}$ relative to calving) was run with production stage entering the model as a repeated measure using an autoregressive covariance matrix (which resulted in the lowest Bayesian information criterion values).

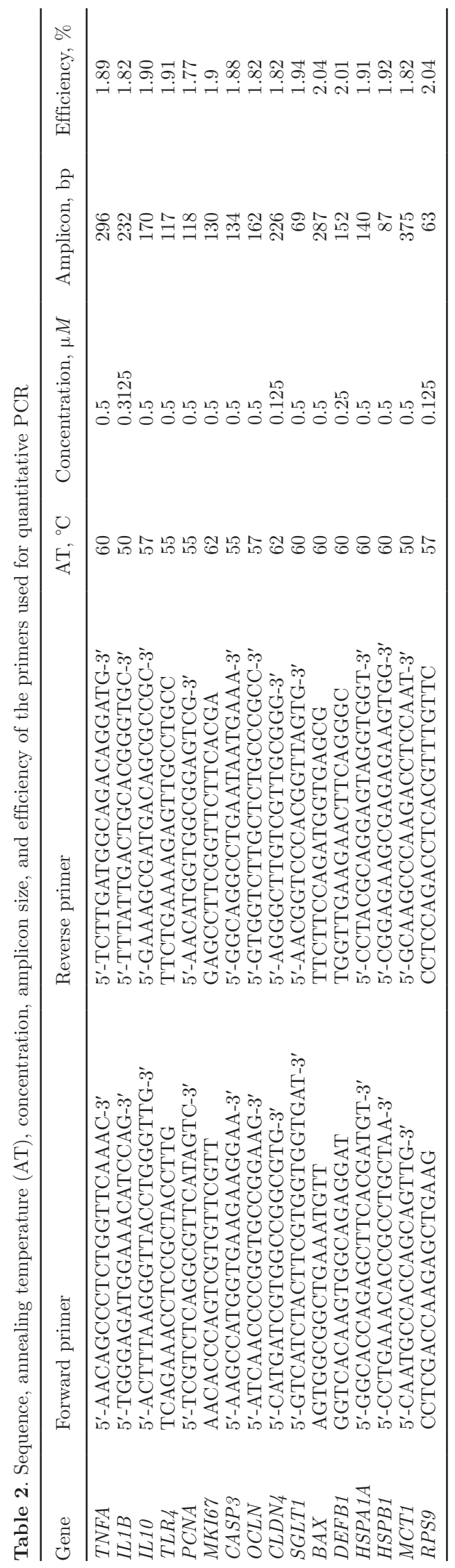




\section{RESULTS AND DISCUSSION}

Dry matter intake during the first 21 DIM was greater $(P<0.05)$ in LY cows $(18.2 \pm 0.77 \mathrm{~kg} / \mathrm{d})$ than in control cows $(15.7 \pm 0.77 \mathrm{~kg} / \mathrm{d})$. Previous studies evaluating the effects of yeast supplementation in lactating cows have not consistently shown changes in feed intake (Jouany, 2006; Bach et al., 2007; Thrune et al., 2009), but to our knowledge this is the first time that intake was recorded in cows that were exposed to live yeast before calving and during lactation. Milk production during the first 21 DIM was also greater $(P<0.05)$ in LY cows $(38.7 \pm 2.85 \mathrm{~kg} / \mathrm{d})$ than in control cows $(32.7 \pm 2.85 \mathrm{~kg} / \mathrm{d})$, which most likely was partly due to the increased DMI observed in LY cows. Although differences in DMI and milk yield between control and LY cows were quite dramatic, the number of animals herein is rather limited to fully evaluate feed intake and milk performance (the objective of the study was centered on rumen and colon changes), and further research is needed before more solid conclusions can be reached. Nevertheless, the results herein would suggest that live yeast supplementation before calving may exert a positive effect on feed intake after calving, which in turn may support increases in milk yield during early lactation.

\section{Gene Expression in the Rumen Epithelium}

Results for gene expression from rumen biopsies are depicted in Table 3. The expression of TLR4, which is mostly known to recognize lipopolysaccharide of gramnegative bacteria, was greatest in the rumen epithelium before calving and progressively decreased as lactation progressed $(P<0.05)$. Furthermore, LY cows had a greater $(P<0.05)$ expression of TLR4 in the rumen epithelium before calving than control cows, which had the lowest TLR4 expression at 21 DIM. Toll-like receptors are capable of recognizing highly conserved microbial molecules and modulate host immune responses via proinflammatory and anti-inflammatory pathways (Bauernfeind et al., 2009; Franchi et al., 2009). These receptors can discriminate between pathogenic and nonpathogenic commensal microbes, and their activation controls intestinal homeostasis (Rakoff-Nahoum et al., 2004) and regulates epithelial barrier and immune responses (Abreu, 2010; Ulluwishewa et al., 2011). In agreement with the observations herein, a decrease in toll-like receptor expression in the rumen epithelium after calving compared with prepartum levels was previously reported by Minuti et al. (2015). Furthermore, Catalani et al. (2010) described a decrease in the expression of TLR 4 in peripheral blood mononuclear cells in cows after calving and hypothesized that this decay could be part of a mechanism of endotoxin tolerance to adapt the cow to consuming high-concentrate diets (which increase exposure to endotoxins in the gastrointestinal tract) during lactation. In fact, mechanisms of endotoxin tolerance through the downregulation of innate immune response have been suggested to avoid the side effects of inflammation by toll-like receptor-interacting proteins (Abreu, 2010), and thus it could be hypothesized that after calving the ruminal epithelium adapts to increased fermentation activity in the rumen through a downregulation of TLR 4 expression.

The expression of TNFA (coding for tumor necrosis factor $\alpha$, a proinflammatory cytokine) in the rumen epithelium was affected by an interaction between treatment and state of production. Expression of TNFA in the rumen epithelium of control cows was lowest $(P<0.05)$ at 21 DIM but in LY cows was kept steady among production stages. The expression of $I L 1 B$ (another proinflammatory cytokine) in the rumen epithelium was not affected by treatment or production stage. However, the expression of IL10 (an antiinflammatory cytokine that counterbalances the effect of proinflammatory cytokines) in the rumen epithelium in control cows was greatest $(P<0.05)$ at 7 DIM, whereas expression in LY cows was greatest before calving. Overall, these results indicate that live yeast may modulate ruminal immunity, which is in agreement with previous studies demonstrating the ability of Saccharomyces cerevisiae to trigger humoral and epithelial immunity in the transition cow (Yuan et al., 2015). It could be speculated that increased expression of IL10 in the rumen epithelium before calving in LY cows could potentially reduce inflammatory responses and that this increased expression of IL10 might be related to interactions with potential changes in the rumen microflora as a consequence of the presence of live yeast, especially because the dry cow ration herein was low in fermentation carbohydrates. Thus, it seems unlikely that changes in the expression of genes coding for inflammation may have been caused by exposure to fermentation end products. Feeding high-concentrate diets during lactation increases the release of ruminal endotoxins, which is directly correlated with an inflammatory response observed after calving (Abaker et al., 2017). However, we could conclude that the increase in the inflammation status in LY cows occurred during the precalving period, whereas in control cows the increase took place postcalving. As previously shown with other probiotics (Genís et al., 2017), it is likely that live yeast may have induced an earlier inflammatory activation in comparison with the control; in turn, when LY cows were exposed to inflammatory stimulus (e.g., an infection or postcalving inflammation caused by a diet change and increased intake), they needed a 
more moderate immune reactivity compared with control cows. Moreover, the increase of TNFA expression in LY cows at 21 DIM could also be linked to the difference in DMI (which would have supplied an increased amount of fermentable carbohydrates to the rumen) observed in LY cows compared with control cows.

Expression of DEFB1 (coding for $\beta$-defensin, an antimicrobial peptide that permeabilizes bacterial cell membranes) in the rumen epithelium was greater $(P<$ $0.05)$ during the dry period than during lactation, with no differences within the first 21 DIM and no influence from yeast supplementation. This observation is a bit puzzling, as expression and production of $\beta$-defensins in the digestive tract have been positively associated with increased bacterial exposure (Ayabe et al., 2000). However, Devant et al. (2016) reported a tendency toward an increased DEFB1 expression in the rumen of fattening bulls fed a high-concentrate ration when their diet was supplemented with straw, which would be similar to the differences observed herein between the dry ration (high in forage) and the lactation ration (rich in concentrate).

The expression of SGLT1 (coding for a transporter involved in the absorption of glucose and galactose) in the rumen epithelium was lowest $(P<0.01)$ at 21 DIM independently of yeast supplementation. This cotransporter participates in the absorption of glucose and it has been reported to be present and active in the rumen of sheep (Aschenbach et al., 2002). The reduced expression of SGLT1 at 21 DIM could be linked to a decreased sympathetic status of the cows compared with dry cows because expression of SGLT1 in the rumen has been demonstrated to be epinephrine dependent (Aschenbach et al., 2002). Different from the results obtained with SGLT1, expression of MCT1, which codes for a protein participating in the absorption of VFA in in the rumen epithelium (Kirat et al., 2006), was not altered by treatment or by production stage. It has been previously reported in goats that the expression of MCT1 in the ventral sac of the rumen is increased when feeding high-concentrate diets (Metzler-Zebeli and Hollmann, 2013). In the current study, we sampled the dorsal sac, and it is possible that accumulation of fermentation end products in that area was lesser than in the lower sac.

The expression of PCNA (coding for a protein essential for cell replication acting as a helper for DNA polymerase) and MKI67 (coding for Ki-67, a protein involved in cell proliferation) in the rumen epithelium was greatest $(P<0.01)$ at 7 DIM independently of yeast supplementation. Both PCNA and MKI67 are indicators of cell proliferation, and thus the results herein suggest an increased cell proliferation in the rumen epithelium at $7 \mathrm{~d}$ postpartum. Ruminal epithelial proliferation has been presumed to be positively associated with increased surface area for nutrient absorption (Dirksen et al., 1985; Baldwin, 1999; Mentschel et al., 2001). Several studies (Bannink et al., 2008, 2012) have reported that cows fed sudden increases of dietary concentrate after parturition had greater rates of rumen epithelial proliferation compared with cows fed gradual increases of dietary concentrate. Such rapid remodeling

Table 3. Expression of selected genes in the rumen epithelium as affected by yeast supplementation, production stage, and their interaction

\begin{tabular}{|c|c|c|c|c|c|c|c|c|c|c|}
\hline Gene & \multicolumn{6}{|c|}{ Treatment $^{1}$} & SE & \multicolumn{3}{|c|}{$P$-value ${ }^{2}$} \\
\hline TLR4 & $0.114^{\mathrm{b}}$ & $0.137^{\mathrm{b}}$ & $0.079^{\mathrm{c}}$ & $0.194^{\mathrm{a}}$ & $0.113^{\mathrm{b}}$ & $0.107^{\mathrm{b}}$ & 0.01 & 0.18 & 0.03 & 0.04 \\
\hline TNFA & $0.022^{\mathrm{ab}}$ & $0.027^{\mathrm{a}}$ & $0.013^{\mathrm{b}}$ & $0.025^{\mathrm{a}}$ & $0.018^{\mathrm{ab}}$ & $0.021^{\mathrm{ab}}$ & 0.003 & 0.83 & 0.16 & 0.04 \\
\hline$I L 1 B$ & 0.065 & 0.059 & 0.040 & 0.070 & 0.031 & 0.047 & 0.08 & 0.48 & 0.14 & 0.18 \\
\hline PCNA & 1.489 & 2.786 & 1.124 & 1.795 & 2.238 & 1.450 & 0.18 & 0.92 & $<0.001$ & 0.24 \\
\hline MKI67 & 0.170 & 0.227 & 0.119 & 0.128 & 0.207 & 0.120 & 0.01 & 0.35 & 0.002 & 0.72 \\
\hline$B A X$ & 0.014 & 0.018 & 0.011 & 0.014 & 0.021 & 0.013 & 0.002 & 0.25 & 0.01 & 0.90 \\
\hline CASP3 & 0.046 & 0.078 & 0.032 & 0.079 & 0.070 & 0.043 & 0.01 & 0.51 & 0.08 & 0.39 \\
\hline$O C L N$ & $0.049^{\mathrm{b}}$ & $0.117^{\mathrm{b}}$ & $0.081^{\mathrm{b}}$ & $0.145^{\mathrm{a}}$ & $0.086^{\mathrm{b}}$ & $0.067^{\mathrm{b}}$ & 0.01 & 0.38 & 0.31 & 0.004 \\
\hline$C L D N 4$ & 1.514 & 1.464 & 1.304 & 1.728 & 1.549 & 1.256 & 0.18 & 0.74 & 0.30 & 0.84 \\
\hline HSPA1A & 0.017 & 0.021 & 0.016 & 0.019 & 0.021 & 0.021 & 0.09 & 0.32 & 0.17 & 0.45 \\
\hline
\end{tabular}

\footnotetext{
${ }^{\mathrm{a}-\mathrm{C}}$ When $\mathrm{T} \times \mathrm{S}$ is significant, uncommon superscripts within a row denote significant differences at $P<0.05$.

${ }^{1}$ Control $=$ cows received no live yeast supplementation; $\mathrm{LY}=$ cows received $3.3 \mathrm{~g} / \mathrm{d}$ of live yeast starting $21 \mathrm{~d}$ before and continuing until 21 $\mathrm{d}$ after calving.

${ }^{2} \mathrm{~T}=$ effect of treatment; $\mathrm{S}=$ effect of production stage (dry or lactating); $\mathrm{T} \times \mathrm{S}=$ interaction between treatment and production state.
} 
of the rumen epithelium postcalving should take place along with an increase in apoptosis, which, as indicated by the increased expression of $B A X$ (coding the BAX proapoptotic protein), was greatest $(P<0.01)$ at 1 wk after calving independent of yeast supplementation. Similarly, expression of $C A S P 3$ (coding for a protein also involved in apoptosis) tended $(P=0.08)$ to be lowest at 21 DIM and highest at 7 DIM independently of yeast supplementation. Overall, the tendency toward (based on $C A S P 3$ ) or actual increased apoptosis activity (based on $B A X$ ) could be indicative of increased proliferation and restructuring of the rumen epithelium right after calving.

The evaluated genes CLDN4 and OCLN code for proteins participating in epithelium integrity through tight junctions (claudin 4 and occludin, respectively), which in the rumen epithelium are mainly located in the stratum granulosum (Graham and Simmons, 2005). Expression of $O C L N$, but not CLDN4, in the rumen epithelium was affected by an interaction $(P<0.01)$ between stage of production and yeast supplementation. Basically, the expression of $O C L N$ was greatest during the first week after calving in control cows, whereas in LY cows it was greatest before calving. Previous studies have also reported an upregulation of tight junction proteins, such as occludin, due to supplementation of live yeast (Rajput et al., 2013) as well as other probiotics (Yang et al., 2015). However, as stated before, changes observed with LY treatment could also be due to indirect consequences of the increased DMI obtained with this treatment. Taken together, these data suggest that probiotics have potential to improve the rumen epithelial barrier through an upregulation of the main proteins involved in tight junction formation, either directly or indirectly as a consequence of a concomitant increase in DMI.

Expression of genes coding for heat-shock proteins of the families A and $\mathrm{B}$ (HSPA1A and $H S P B 1$, respectively) in the rumen was not altered by production stage or by yeast supplementation. These proteins participate in the maintenance of proper protein folding and prevent their aggregation. Kern et al. (2017) described that the expression of HSPB1 increased when beef steers were transitioned from a low- to a high-concentrate ration, suggesting that under adverse conditions the expression of this gene would be increased. Moreover, Catalani et al. (2010) reported an increase of heat shock proteins in postcalving dairy cows, suggesting that these proteins could be involved in resolving the oxidative stress after calving. However, the shift from a dry to a lactation ration did not elicit such a change in the rumen epithelium expression profile herein.

Together, these results suggest that gene expression in the rumen epithelium of dry cows changes in less than $7 \mathrm{~d}$ after exposure to live yeast, especially the expression of those genes involved in the immune response. However, 2 questions remain to be elucidated: (1) how some, if any, of the measured changes prepartum may modulate the cellular stress or integrity and immune responses postcalving and (2) to what extent changes are due to the postcalving increase in DMI observed with live yeast supplementation and to what extent changes are a direct consequence of live yeast supplementation.

\section{Gene Expression in the Colon Mucosa}

Results for gene expression from colon biopsies are depicted in Table 4. Fluctuations in expression of the selected genes in the colon between the 2 stages of production and 2 treatments were much smaller than the ones observed in the rumen, probably in part because the amount of live yeast reaching the colon is lower than the amount reaching the rumen (Durand-Chaucheyras et al., 1998) and because nutrient substrate from the digesta should fluctuate less than in the rumen.

There were no differences in TLR 4 expression in the colon mucosa (Table 4) between treatments or production stages, but the expression of TLR 4 in the colon mucosa was greater $(P<0.05)$ than that observed in the rumen (Table 3 ), which suggests that the colon may play a more important role in the gastrointestinal immune system compared with the rumen, as it has been reported in calves (Malmuthuge et al., 2013). However, the expression of DEFB1 in the colon mucosa was 10 times greater $(P<0.05)$ than in the rumen epithelium, and, contrary to the TLR 4 , it was greater $(P<0.05)$ in LY cows than in control cows. These findings may indicate (1) that DEFB1 seems to be more important in the colon than in the rumen and (2) that the colon of LY cows was more active at regulating the luminal microbiota than the colon of control cows at all production stages. Last, there was a tendency $(P=0.07)$ for control cows to have a greater expression of $B A X$ (involved in apoptosis) than LY cows across all production stages, which would indicate that yeast supplementation tended to reduce apoptosis in the colon (and perhaps a lower degree of mucosa remodeling). Emenaker et al. (2001) described a potent inhibitory effect of short-chain fatty acids on the expression of $B A X$ in the colon mucosa of humans. Because supplementation of live yeast has been reported to increase NDF digestion in the rumen (Chaucheyras-Durand et al., 2008), it could be hypothesized that live yeast resulted in a lower proportion of NDF reaching the hindgut, leading to a lower concentration of short-chain fatty acids, which might explain the tendency toward lower expression of $B A X$ in the colon mucosa observed herein. 
Table 4. Expression of selected genes in the colon epithelium as affected by yeast supplementation, production stage, and their interaction

\begin{tabular}{|c|c|c|c|c|c|c|c|c|c|c|}
\hline \multirow[b]{2}{*}{ Gene } & \multicolumn{6}{|c|}{ Treatment $^{1}$} & \multirow[b]{2}{*}{$\mathrm{SE}$} & \multicolumn{3}{|c|}{$P$-value ${ }^{2}$} \\
\hline & $-2 \mathrm{wk}$ & $+1 \mathrm{wk}$ & $+3 \mathrm{wk}$ & $-2 \mathrm{wk}$ & $+1 \mathrm{wk}$ & $+3 \mathrm{wk}$ & & $\mathrm{T}$ & S & $\mathrm{T} \times \mathrm{S}$ \\
\hline$\overline{I L 10, \times 10^{2}}$ & 0.017 & 0.011 & 0.016 & 0.008 & 0.018 & 0.015 & 0.09 & 0.61 & 0.69 & 0.24 \\
\hline TNFA & 0.149 & 0.144 & 0.131 & 0.100 & 0.132 & 0.185 & 0.02 & 0.95 & 0.75 & 0.52 \\
\hline TLR4 & 0.255 & 0.219 & 0.210 & 0.135 & 0.164 & 0.236 & 0.03 & 0.16 & 0.73 & 0.24 \\
\hline MKI67 & 0.340 & 0.238 & 0.260 & 0.148 & 0.245 & 0.234 & 0.03 & 0.17 & 0.99 & 0.28 \\
\hline SGLT1 & 0.076 & 0.083 & 0.079 & 0.051 & 0.072 & 0.074 & 0.006 & 0.19 & 0.49 & 0.72 \\
\hline$B A X$ & 0.062 & 0.068 & 0.088 & 0.035 & 0.057 & 0.075 & 0.007 & 0.07 & 0.07 & 0.74 \\
\hline CASP3 & 0.082 & 0.078 & 0.055 & 0.064 & 0.096 & 0.090 & 0.07 & 0.61 & 0.86 & 0.66 \\
\hline$O C L N$ & 0.153 & 0.109 & 0.096 & 0.079 & 0.077 & 0.103 & 0.02 & 0.17 & 0.72 & 0.40 \\
\hline$C L D N_{4}$ & 0.311 & 0.523 & 0.615 & 0.395 & 0.429 & 0.613 & 0.08 & 0.97 & 0.23 & 0.81 \\
\hline HSPA1A & 0.064 & 0.043 & 0.086 & 0.019 & 0.095 & 0.044 & 0.23 & 0.64 & 0.77 & 0.56 \\
\hline
\end{tabular}

${ }^{1}$ Control $=$ cows received no live yeast supplementation; $\mathrm{LY}=$ cows received $3.3 \mathrm{~g} / \mathrm{d}$ of live yeast starting $21 \mathrm{~d}$ before and continuing until 21 d after calving.

${ }^{2} \mathrm{~T}=$ effect of treatment; $\mathrm{S}=$ effect of production stage (dry or lactating); $\mathrm{T} \times \mathrm{S}=$ interaction between treatment and production state.

In summary, the use of an endoscope allowed us to study changes in the epithelia of both the rumen and the distal hindgut of dairy cattle. The results of gene expression presented herein reflect dynamics of rumen adaptation to increased supply of concentrate after calving, including epithelium remodeling and a reduction of the expression of TLR4 along with an increase in the expression of the anti-inflammatory $I L 10$. We hypothesize that the downregulation of TLR4 in the rumen epithelium after calving could be part of an adaptation mechanism to high-concentrate diets. Supplementing live yeast before and after calving increased the expression of TLR4, IL10 (potentially preparing and modulating the inflammatory status), and OCLN in the epithelium of the dorsal sac of the rumen before calving but kept the expression of TNFA expression stable in comparison with unsupplemented cows. These changes could be due to a direct effect of live yeast or an indirect effect consequent of the increased DMI in early lactation elicited by live yeast supplementation. In the distal colon, changes in gene expression were more modest, although expression of genes related to immune response such as TLR 4 and DEFB1 expression was much greater than in the rumen, and the expression of DEFB1 was further stimulated by live yeast supplementation.

\section{ACKNOWLEDGMENTS}

We thank Lallemand Animal Nutrition (Blagnac, France) for partially funding this work. This research was supported by the CERCA program from Generalitat de Catalunya (Barcelona, Catalonia).

\section{REFERENCES}

Abaker, J. A., T. L. Xu, D. Jin, G. J. Chang, K. Zhang, and X. Z. Shen. 2017. Lipopolysaccharide derived from the digestive tract provokes oxidative stress in the liver of dairy cows fed a high-grain diet. J. Dairy Sci. 100:666-678. https://doi.org/10.3168/jds.2016 $-10871$.

Abreu, M. T. 2010. Toll-like receptor signalling in the intestinal epithelium: How bacterial recognition shapes intestinal function. Nat. Rev. Immunol. 10:131-144. https://doi.org/10.1038/nri2707.

AOAC (Association of Official Analytical Chemists). 1990. Official Methods of Analysis. 15th ed. AOAC, Arlington, VA.

Aschenbach, J. R., T. Borau, and G. Gäbel. 2002. Glucose uptake via SGLT-1 is stimulated by beta(2)-adrenoceptors in the ruminal epithelium of sheep. J. Nutr. 132:1254-1257.

Ayabe, T., D. P. Satchell, C. L. Wilson, W. C. Parks, M. E. Selsted, and A. J. Ouellette. 2000. Secretion of microbicidal alphadefensins by intestinal Paneth cells in response to bacteria. Nat. Immunol. 1:113-118.

Bach, A., C. Iglesias, and I. Busto. 2004. Technical note: A computerized system for monitoring feeding behavior and individual feed intake of dairy cattle. J. Dairy Sci. 87:4207-4209. https://doi.org/ 10.3168/jds.S0022-0302(04)73565-1.

Bach, A., C. Iglesias, and M. Devant. 2007. Daily rumen pH pattern of loose-housed dairy cattle as affected by feeding pattern and live yeast supplementation. Anim. Feed Sci. Technol. 136:146-153. https://doi.org/10.1016/j.anifeedsci.2006.09.011.

Bach, A., I. K. Yoon, M. D. Stern, H. G. Jung, and H. Chester-Jones, 1999. Effects of type of carbohydrate supplementation to lush pasture on microbial fermentation in continuous culture. J. Dairy Sci. 82:153-160. https://doi.org/10.3168/jds.S0022-0302(99)75219-7.

Baldwin, R. L. V. I. 1999. The proliferative actions of insulin, insulinlike growth factor-I, epidermal growth factor, butyrate and propionate on ruminal epithelial cells in vitro. Small Rumin. Res. $32: 261-268$

Bannink, A., J. France, S. Lopez, W. J. J. Gerrits, E. Kebreab, S. Tamminga, and J. Dijkstra. 2008. Modeling the implications of 
feeding strategy on rumen fermentation and functioning of the rumen wall. Anim. Feed Sci. Technol. 143:3-26.

Bannink, A., W. J. J. Gerrits, J. France, and J. Dijkstra. 2012. Variation in rumen fermentation and the rumen wall during the transition period in dairy cows. Anim. Feed Sci. Technol. 172:80-94. https://doi.org/10.1016/j.anifeedsci.2011.12.010.

Bauernfeind, F. G., G. Horvath, A. Stutz, E. S. Alnemri, K. MacDonald, D. Speert, T. Fernandes-Alnemri, J. Wu, B. G. Monks, K. A. Fitzgerald, V. Hornung, and E. Latz. 2009. Cutting edge: NF-kappaB activating pattern recognition and cytokine receptors license NLRP3 inflammasome activation by regulating NLRP3 expression. J. Immunol. 183:787-791. https://doi.org/10.4049/ jimmunol.0901363.

Beharka, A. A., T. G. Nagaraja, J. L. Morrill, G. A. Kennedy, and R. D. Klemm. 1998. Effects of form of the diet on anatomical, microbial, and fermentative development of the rumen of neonatal calves. J. Dairy Sci. 81:1946-1955.

Bevans, D. W., K. A. Beauchemin, K. S. Shwartzkopf-Genswein, J. J. McKinnon, and T. A. McAllister. 2005. Effect of rapid or gradual grain adaptation on subacute acidosis and feed intake by feedlot cattle. J. Anim. Sci. 83:1116-1132.

Brown, M. S., C. H. Ponce, and R. Pulikanti. 2006. Adaptation of beef cattle to high-concentrate diets: Performance and ruminal metabolism. J. Anim. Sci. 84:E25-E33.

Castells, L., A. Bach, A. Aris, and M. Terré. 2013. Effects of forage provision to young calves on rumen fermentation and development of the gastrointestinal tract. J. Dairy Sci. 96:5226-5236. https:// doi.org/10.3168/jds.2012-6419.

Catalani, E., M. Amadori, A. Vitali, U. Bernabucci, A. Nardone, and N. Lacetera. 2010. The Hsp72 response in periparturient dairy cows: Relationships with metabolic and immunological parameters. Cell Stress Chaperones 15:781-790. https://doi.org/10.1007/ s12192-010-0186-x.

Chaucheyras-Durand, F., N. D. Walker, and A. Bach. 2008. Effects of active dry yeasts on the rumen microbial ecosystem: Past, present and future. Anim. Feed Sci. Technol. 145:5-26. https://doi.org/10 .1016/j.anifeedsci.2007.04.019

de Ondarza, M. B., C. J. Sniffen, L. Dussert, E. Chevaux, J. Sulivan, and N. Walker. 2010. Case study: Multiple-study analysis of the effect of live yeast on milk yield, milk component content and yield, and feed efficiency. Prof. Anim. Sci. 26:661-666.

Devant, M., G. B. Penner, S. Marti, B. Quintana, F. Fàbregas, A. Bach, and A. Aris. 2016. Behavior and inflammation of the rumen and cecum in Holstein bulls fed high-concentrate diets with different concentrate presentation forms with or without straw supplementation. J. Anim. Sci. 94:3902-3917. https://doi.org/10.2527/ jas.2016-0594.

Dieho, K., J. Dijkstra, J. T. Schonewille, and A. Bannink. 2016. Changes in ruminal volatile fatty acid production and absorption rate during the dry period and early lactation as affected by rate of increase of concentrate allowance. J. Dairy Sci. 99:5370-5384. https://doi.org/10.3168/jds.2015-10819.

Dirksen, G. U., H.-G. Liebich, and E. Mayer. 1985. Adaptive changes of the ruminal mucosa and their functional and clinical significance. Bov. Pract. 20:116-120.

Durand-Chaucheyras, F., G. Fonty, G. Bertin, M. Théveniot, and P. Gout. 1998. Fate of Levucell SC I-1077 yeast additive during digestive transit in lambs. Reprod. Nutr. Dev. 38:275-280.

Emenaker, N. J., G. M. Calaf, D. Cox, M. D. Basson, and N. Qureshi. 2001. Short-chain fatty acids inhibit invasive human colon cancer by modulating uPA, TIMP-1, TIMP-2, mutant p53, Bcl-2, Bax, p21 and PCNA protein expression in an in vitro cell culture model. J. Nutr. 131:3041S-3046S.

Fernando, S. C., H. T. Purvis, F. Z. Najar, L. O. Sukharnikov, C. R. Krehbiel, T. G. Nagaraja, B. A. Roe, and U. DeSilva. 2010. Rumen microbial population dynamics during adaptation to a highgrain diet. Appl. Environ. Microbiol. 76:7482-7490. https://doi .org/10.1128/AEM.00388-10.

Franchi, L., T. Eigenbrod, and G. Núñez. 2009. Cutting edge: TNFalpha mediates sensitization to ATP and silica via the NLRP3 in- flammasome in the absence of microbial stimulation. J. Immunol. 183:792-796.

Genís, S., A. Sánchez-Chardi, A. Bach, F. Fàbregas, and A. Arís. 2017. A combination of lactic acid bacteria regulates Escherichia coli infection and inflammation of the bovine endometrium. J. Dairy Sci. 100:479-492. https://doi.org/10.3168/jds.2016-11671.

Górka, P., Z. M. Kowalski, P. Pietrzak, A. Kotunia, W. Jagusiak, J. J. Holst, P. Guilloteau, and R. Zabielski. 2011. Effect of method of delivery of sodium butyrate on rumen development in newborn calves. J. Dairy Sci. 94:5578-5588. https://doi.org/10.3168/jds 2011-4166.

Graham, C., and N. L. Simmons. 2005. Functional organization of the bovine rumen epithelium. Am. J. Physiol. Regul. Integr. Comp. Physiol. 288:R173-R181.

Jouany, J. P. 2006. Optimizing rumen functions in the close-up transition period and early lactation to drive dry matter intake and energy balance in cows. Anim. Reprod. Sci. 96:250-264. https:// doi.org/10.1016/j.anireprosci.2006.08.005.

Kern, R. J., C. M. Zarek, A. K. Lindholm-Perry, L. A. Kuehn, W. M. Snelling, H. C. Freetly, H. C. Cunningham, and A. M. Meyer. 2017. Ruminal expression of the NQO1, RGS5, and ACAT1 genes may be indicators of feed efficiency in beef steers. Anim. Genet. 48:90-92. https://doi.org/10.1111/age.12490.

Kirat, D., J. Masuoka, H. Hayashi, H. Iwano, H. Yokota, H. Taniyama, and S. Kato. 2006. Monocarboxylate transporter 1 (MCT1) plays a direct role in short-chain fatty acids absorption in caprine rumen. J. Physiol. 576:635-647. https://doi.org/10.1113/jphysiol .2006.115931.

Malmuthuge, N., M. Li, L. A. Goonewardene, M. Oba, and L. L. Guan. 2013. Effect of calf starter feeding on gut microbial diversity and expression of genes involved in host immune responses and tight junctions in dairy calves during weaning transition. J. Dairy Sci. 96:3189-3200. https://doi.org/10.3168/jds.2012-6200.

Martens, H., I. Rabbani, Z. Shen, F. Stumpff, and C. Deiner. 2012. Changes in rumen absorption processes during transition. Anim. Feed Sci. Technol. 172:95-102. https://doi.org/10.1016/j.anifeedsci 2011.12.011.

Mentschel, J., R. Leiser, C. Mulling, C. Pfarrer, and R. Claus. 2001. Butyric acid stimulates rumen mucosa development in the calf mainly by a reduction of apoptosis. Arch. Tierernahr. 55:85-102.

Metzler-Zebeli, B. U., and M. Hollmann. 2013. Epithelial response to high-grain diets involves alteration in nutrient transporters and $\mathrm{Na} / \mathrm{K}-\mathrm{ATP}$ ase mRNA expression in rumen and colon of goats. J. Anim. Sci. 91:4256-4266. https://doi.org/10.2527/jas.2012-5570.

Minuti, A., A. Palladino, M. J. Khan, S. Alqarni, A. Agrawal, F. Piccioli-Capelli, F. Hidalgo, F. C. Cardoso, E. Trevisi, and J. J. Loor. 2015. Abundance of ruminal bacteria, epithelial gene expression, and systemic biomarkers of metabolism and inflammation are altered during the peripartal period in dairy cows. J. Dairy Sci. 98:8940-8951. https://doi.org/10.3168/jds.2015-9722.

Nagaraja, T. G., and E. C. Titgemeyer. 2007. Ruminal acidosis in beef cattle: The current microbiological and nutritional outlook. J. Dairy Sci. 90:E17-E38. https://doi.org/10.3168/jds.2006-478.

NRC. 2001. Nutrient Requirements of Dairy Cattle. 7 th rev. ed. National Academy Press, Washington, DC.

Offner, A., A. Bach, and D. Sauvant. 2003. Quantitative review of in situ starch degradation in the rumen. Anim. Feed Sci. Technol. 106:81-93. https://doi.org/10.1016/S0377-8401(03)00038-5.

Penner, G. B., K. A. Beauchemin, and T. Mutsvangwa. 2007. Severity of ruminal acidosis in primiparous Holstein cows during the periparturient period. J. Dairy Sci. 90:365-375.

Pfaffl, M. W., A. Tichopad, C. Prgomet, and T. P. Neuvians. 2004. Determination of stable housekeeping genes, differentially regulated target genes and sample integrity: BestKeeper-Excel-based tool using pair-wise correlations. Biotechnol. Lett. 26:509-515.

Rajput, I. R., L. Y. Li, X. Xin, B. B. Wu, Z. L. Juan, Z. W. Cui, D. Y. Yu, and W. F. Li. 2013. Effect of Saccharomyces boulardii and Bacillus subtilis $\mathrm{B} 10$ on intestinal ultrastructure modulation and mucosal immunity development mechanism in broiler chickens. Poult. Sci. 92:956-965. https://doi.org/10.3382/ps.2012-02845. 
Rakoff-Nahoum, S., J. Paglino, F. Eslami-Varzaneh, S. Edberg, and R. Medzhitov. 2004. Recognition of commensal microflora by toll-like receptors is required for intestinal homeostasis. Cell 118:229-241.

Reynolds, C. K., B. Dürst, B. Lupoli, D. J. Humphries, and D. E. Beever. 2004. Visceral tissue mass and rumen volume in dairy cows during the transition from late gestation to early lactation. J. Dairy Sci. 87:961-971. https://doi.org/10.3168/jds.S0022 -0302(04)73240-3.

Steele, M. A., J. Croom, M. Kahler, O. AlZahal, S. E. Hook, K. Plaizier, and B. W. McBride. 2011b. Bovine rumen epithelium undergoes rapid structural adaptations during grain-induced subacute ruminal acidosis. Am. J. Physiol. Regul. Integr. Comp. Physiol 300:R1515-R1523. https://doi.org/10.1152/ajpregu.00120.2010.

Steele, M. A., G. Vandervoort, O. AlZahal, S. E. Hook, J. C. Matthews, and B. W. Mcbride. 2011a. Rumen epithelial adaptation to high-grain diets involves the coordinated regulation of genes involved in cholesterol homeostasis. Physiol. Genomics 43:308-316. https://doi.org/10.1152/physiolgenomics.00117.2010.

Terré, M., G. Maynou, A. Bach, and M. Gauthier. 2015. Effect of Saccharomyces cerevisiae CNCM I-1077 supplementation on performance and rumen microbiota of dairy calves. Prof. Anim. Sci. 31:153-158. https://doi.org/10.15232/pas.2014-01384.

Thrune, M., A. Bach, M. Ruiz Moreno, M. D. Stern, and J. G. Linn. 2009. Effects of Saccharomyces cerevisiae on ruminal $\mathrm{pH}$ and microbial fermentation in dairy cows: Yeast supplementation on rumen fermentation. Livest. Sci. 124:261-265. https://doi.org/10 $.1016 /$ j.livsci.2009.02.007.
Ulluwishewa, D., R. Anderson, W. McNabb, P. Moughan, J. Wells, and N. Roy. 2011. Regulation of tight junction permeability by intestinal bacteria and dietary components. J. Nutr. 141:769-776.

Vandesompele, J., K. De Preter, F. Pattyn, B. Poppe, N. Van Roy, A. De Paepe, and F. Spelema. 2002. Accurate normalization of real-time quantitative RT-PCR data by geometric averaging of multiple internal control genes. Genome Biol. 3:research0034.

Van Soest, P. J., J. B. Robertson, and B. I. Lewis. 1991. Methods for dietary fiber, neutral detergent fiber and non-starch polysaccharide in relation to animal nutrition. J. Dairy Sci. 74:3583-3597.

Yang, F., A. Wang, X. Zeng, C. Hou, H. Liu, and S. Qiao. 2015. Lactobacillus reuteri $\mathrm{I} 5007$ modulates tight junction protein expression in IPEC-J2 cells with LPS stimulation and in newborn piglets under normal conditions. BMC Microbiol. 15:32. https://doi.org/ 10.1186/s12866-015-0372-1.

Yuan, K., L. G. D. Mendonça, L. E. Hulbert, L. K. Mamedova, M. B. Muckey, Y. Shen, C. C. Elrod, and B. J. Bradford. 2015. Yeast product supplementation modulated humoral and mucosal immunity and uterine inflammatory signals in transition dairy cows. J. Dairy Sci. 98:3236-3246. https://doi.org/10.3168/jds.2014-8469.

Zhao, G.-Y., and Y.-B. Sun. 2010. Effects of volatile fatty acids on IGF-I, IGFBP-3, GH, insulin and glucagon in plasma, and IGF-I and IGFBP-3 in different tissues of growing sheep nourished by total intragastric infusions. Asian-Australas. J. Anim. Sci. 23:366371. 